\title{
The Role of the Junior College Library
}

The basic goals of junior college libraries do not differ greatly from those of four-year college libraries. These goals were quite well defined in theory some years ago, but efforts to implement them have, with a handful of notable exceptions, been unsuccessful. Inadequate funding has, in part, been to blame, but other factors must share in this blame as well. Renewed vision and new vigor must be sought in several quarters if the fulfilment of junior college library goals is to be attained.

$\mathrm{T}_{\mathrm{H}}$ HE GOALS of junior college libraries are much the same as those of four-year college libraries. Both seek to provide good reference and circulation service to students and faculty. They seek to make the library the heart of the campus, to make it a vital part of the college educational program. There is very little difference, basically, in the goals of fourand two-year college libraries and the campus roles they should play. Of course, the goals of individual colleges differ somewhat one from another, but the basic goals of different kinds of colleges will ever be the same. No one has spelled out these roles more clearly than Harvie Branscomb ${ }^{1}$ and B. Lamar Johnson, ${ }^{2}$ and their ideas will be summarized briefly.

In the years since its inauguration, other colleges have adopted parts of

\footnotetext{
${ }^{1}$ Harvie Branscomb, Teaching with Books; A Study of College Libraries (New Haven: Shoe String Press, 1964).

'B. Lamar Johnson, Vitalizing College Libraries (Chicago: ALA, 1939); B. Lamar Johnson and Eloise Lindstrom, The Librarian and the Teacher in General Education; A Report of Instructional Activities at Stephens College (Chicago: ALA, 1948).
}

Dr. Harvey is Dean of the Graduate School of Library Science in Drexel Institute of Technology. This paper was read before ACRL's Junior College Section at the Detroit Conference on July 7. the Stephens program, but all of the original program still represents a goal worth working toward. Very few libraries have reached the level of service described therein. At Stephens the librarian and the dean of instruction were originally the same person, B. Lamar Johnson, and instructors and librarians were merged into a single instructional staff in an effort to coordinate the teaching of instructors with the educational services of librarians. In this college the librarian was a partner with the instructor on an equal basis. This was an attempt to bring the library to its full realization of importance, to make it heavily used, to obtain an adequate return on the investment in it, and to move away as far as possible from the traditional custodial operation so common in other college libraries. Faculty members became acquainted with the book collection and staff and used them extensively in classwork. Since faculty members regarded books as essential to student achievement of individual objectives, the library assumed unusual importance.

A cardinal principle was that of making books a constant and natural part of each Stephens student's environment so she could learn their helpfulness for 
both study and recreation. In addition to the main library, there were divisional libraries with their own staff members for the branches of learning in the student's curriculum. For specific courses, classroom libraries were established so that books could be a constant part of the classroom scene. There were dormitory libraries to bring books closer to students' living quarters and to encourage pleasure reading and the development of lifetime reading habits. Students were also encouraged to build personal libraries.

Librarians worked closely with students and could provide information for instructors on assignments creating special difficulties. Many course units had sections listing supplementary materials. Obviously there was extensive duplication of titles. Often instructors held office hours in the library.

For students to obtain the maximum value from books, however, they had to learn how to use them effectively, so an extensive program of instruction in library and book use was given in firstyear orientation. This was thought to be especially important for students transferring to four-year colleges.

All audio-visual materials were considered part of the library collection, and their extensive use was encouraged since Stephens believed they made learning easier. The library's audio-visual center was the logical storehouse, and these materials were considered to be merely an extension of the traditional books and periodicals that librarians were accustomed to serve. Certain of these materials, reproductions of paintings, and phonograph records, were circulated outside the building for home use.

The course, Masterpieces of World Literature can serve as a concrete example of Stephens' policy. It was taught in a classroom adjoining the literature stacks of the main library, and each student chose a book for report in conference with the librarian and the instruc- tor. Reading assignments were highly individualized, and personal and extensive reading was required so that the student could enlarge his acquaintance with world literature.

Harvie Branscomb in Teaching with Books said instruction through textbooks and lectures addressed to the entire class provided uniform fare for students who differed widely in background and special interests and whose differences should be recognized. Furthermore, in laborious fashion, textbooks and lectures failed to introduce students to great literature and gave them a one-sided and predigested view of the field. These old-fashioned methods of teaching divided knowledge artificially into small compartments which had little connection in the student's mind. Emphasis should have been on the individual student reading material at his own pace, suited to his own interests, and therefore most satisfying to him.

Librarians were urged to de-emphasize the traditional closed reserve book department, and to emphasize instead the open reserve area and two-week book circulation from which the student could choose books related to his individual interests and study them at length. The library should be the student's laboratory.

Branscomb was critical of librarians who emphasized processing over service. He pointed out faculty members' failure to make effective use of the library in their teaching. Surprisingly, he showed that undergraduates did not use the library very much, but found a correlation between library use and scholastic standing. Several colleges were described where student reading had been greatly increased and where books had been made more accessible. Branscomb concluded by describing the responsibilities of the college president and librarian in encouraging reading and library use.

Many activities are called for if we 
are to carry out the roles outlined by Johnson and Branscomb. We must make the faculty member realize the variety and value of the services the library can provide for him. The junior college library will never realize its potential until every course is library-oriented and heavily dependent upon the library.

Each faculty member should synchronize his course work with study in the library. In carrying this out he should know library resources, plan assignments in advance and in cooperation with the librarian, and make sure materials are available. Frequent interviews are needed with reference librarians to discuss library needs and to learn about materials potentially helpful in classes. In this picture the library becomes essential to the faculty member's success in teaching, and he has almost daily contact with it. ${ }^{3}$

Louis Shores has said that classroomfocused teaching was teacher-centered and that library-focused learning was student-centered. He has pointed out the growing trend toward independent work and has suggested that this trend should bring the library into greater prominence. In fact it may ultimately reduce the status of the classroom teacher to an auxiliary position. ${ }^{4}$

As for library services offered, all services now being given should be increased or enlarged. As a rule, the problem is not to decide whether or not a particular service should be offered, but to decide when the staff can start giving it. Don't ask why, ask when! Of course major personnel increases may be needed to carry out more extensive services for faculty and students, and this requires much greater financial investment in the library.

Intensive reference service is needed. In such service the subject needs of faculty members may be ascertained, defin-

\footnotetext{
${ }^{3}$ Louis R. Wilson, The Librarian and College Instruction (New York: H. W. Wilson Company, 1951). "Louis Shores, "The Library Centered Junior College," North Carolina Libraries, XXIII (Fall 1964), 8-13.
}

itive bibliographies drawn up and mailed to them. This program should be followed with selective dissemination of information, a term borrowed from information science. In this program, faculty members' subject interests are ascertained and listed. Library staff members check incoming material against these lists each day and when material is received in a faculty member's field, notification or a photocopy of it is sent to him. Of course, these services are often carried out on a small scale now but should be fully organized and put into operation in all colleges. If given, they would involve sending photocopies and references by the thousands to each college faculty.

In order to provide good reading guidance service to students, it is necessary to keep individual reading records for them. Only with such records can the faculty and librarians understand students' reading patterns and interests and work closely with them on their reading development.

Role differences between junior and senior college libraries exist primarily in the last two years of college. This means, for instance, for the junior college, that there are no upperclass subject majors to be served, students to be prepared for graduate work, departmental libraries to be administered, nor faculty research materials to be purchased. But this library may need to work closely with community groups in providing good adult education material on such subjects as bridge playing and modern dancing. It probably needs more material aimed at the disadvantaged, the inferior student, and the poor reader, and perhaps more material on a secondary school level. Since the junior college student needs more counseling than his four-year college counterpart because junior college student bodies are somewhat inferior scholastically and are less certain of their plans, the library should provide more than usual help for the 
counseling bureau. ${ }^{5}$ The depth of its book and serial collections need not be as great as those of the four-year college, but subject matter must be covered as broadly.

The book collection will be influenced by the administrative decision to emphasize terminal courses or college transfer courses. In a terminal program the practical arts will be emphasized and a more technical book collection required, perhaps even a better technical book collection than is found in the four-year college. Library use will decrease as shop, laboratory work, and typing room experience increases. With emphasis on college transfers, the collection will more nearly resemble that of a four-year liberal arts college, strong in history, literature, the arts, and the social sciences. The college transfer student body is usually the more library oriented of the two.

The library should have a liberalizing, generalizing, and broadening influence on the faculty and student body. It should make college students and faculty conscious of ideas and reading outside their own course of study, outside the curriculum and their own worlds. This same goal exists in the four-year college.

This role deals primarily with public service activities since they are primary. The role in processing and administration is also much the same as that of the senior college. These library activities should be operated economically and should assist the library's public services.

What, however, is the state of the art of junior college librarianship? This question can be interpreted in two senses: what is the state of the theory of junior college librarianship, and what is the state of the practice of junior college librarianship?

In attempting to answer these ques-

\footnotetext{
s Burtor Clark, The Open Door College: A Case Study (New York: MeGraw-Hill, 1960).
}

tions, it may be safely said that the theory is much further developed than the practice. The state of theoretical development has been comparatively good ever since the role of the college library was first developed by Branscomb and Johnson. But there is almost no other aspect of librarianship where the gap is so great between theory and practice; junior college libraries are among the poorest kinds of libraries. A recent article in the Junior College Journal spelled out by category a low opinion of their practice. ${ }^{6}$ To quote Robert Jordan in 1961: "I would like to emphasize that conditions in the average junior college library today are deplorable, if not shocking." 7

The situation has not improved by 1965 ; in fact it has probably worsened as the number of community colleges has proliferated. According to Samore, the percentage of junior college libraries falling below ACRL standards increased between 1960 and 1962. Of junior colleges in 1962, 91 per cent were below ACRL standards in volumes, 85 per cent in personnel, and 50 per cent in their expenditure percentage. Corresponding percentages for four-year colleges were not quite that bad. ${ }^{8}$

Of course the practice of college librianship in general is not much further developed now than it was a generation ago. It is still in the trial and error stage. Less than 10 per cent of college courses are dependent upon the general collection and only 25 per cent on the reserve collection. The library serves essentially a custodial rather than an educational function and is not heavily used. Large collections are being developed, but service of them is still on a mass, supermarket kind of level. Budget planning

\footnotetext{
'John F. Harvey, "The Role of the Junior College Library in Classroom Instruetion," Junior College Journal, XXXII (April 1964), 441-47.

"Robert T. Jordan, "Schools, Not Standards," ALA Bulletin, LV (June 1961), 565-67.

8 Theodore Samore, Library Statistics of College and Universities, 1961-62, Part II, Analytical Report (Washington: U.S. Office of Education, 1964).
} 
usually ignores the educational service which should be provided. ${ }^{9}$

Are institutional changes needed to enable the junior college library to carry out its role successfully? Yes, very fundamental changes are needed. A glance at the junior college itself shows a basic difficulty. The base of financial support is much too small to support a decent college library, because the student body is too small. The curse of smallness is much with us in our many one-man libraries, in public libraries, and colleges. Probably at least one thousand full-time students are needed to support a library properly, and a minimum budget for a good library is $\$ 50,000$. At some junior colleges this is one third or one half of the entire college budget! Total junior college educational expenditures, however, average $\$ 240,000$.

The inferiority of the junior college itself is the primary cause of the inferiority of the library. Until the colleges find themselves, attract respectable enrollments and good budgets, and are able to offer strong programs, the library's role will not be realized nor will more than isolated examples of superior programs be available.

A hopeful sign is the growth of enrollment. As existing colleges grow, they should have more money with which to support their libraries. However, per student support may not improve. The continued proliferation of new colleges is not encouraging since most new junior college libraries start out with nothing and grow slowly through continued inferiority. Amalgamation of two colleges into one is a solution which should be practiced more often.

The ACRL standards are quite satisfactory as minimums. Obviously the standards are low, but they take into consideration the current practice of these libraries. In some of the early standards,

\footnotetext{
John F. Harvey, "The State of the College Library Art," Library Journal, LXXXVI (February 1, 1961), 513-15.
}

use was given greater prominence than it is now, but it is still the primary criterion.

Recently the librarians of some Philadelphia colleges were asked whether or not in the last decade they had seen an increase in per student library circulation and an improvement in the quality of use. Their answers were usually "yes" to the per student increase in quantitative use, and usually "no" to increase in qualitative use. Such increases show improvement in service and some greater realization of the proper role in the college.

We might look to the library schools to produce research providing a better basis for appraising the role and activities of junior college libraries. We might also hope a few junior college librarians would distill their administrative experiences and produce a framework for understanding common administrative situations in different settings. But little or no useful research is being produced and no wise manuals of administration have been recently published.

It is too bad that other colleges have not tried out the Stephens idea of making the librarian the dean. In the one example we have it seems to have been very successful. But why was it not copied elsewhere? Does this relate somehow to the personalities of librarians? Or of deans?

And it is too bad that Branscomb's hopes for college libraries have seldom been realized. He attributes this failure to: (1) the hostility with which college librarians greeted his book originally because of its emphasis on subject specialization; and (2) the fact that the groups for which the book was intended, the president and the faculty, did not see or use it. ${ }^{10}$

What should the library's relationship be to the new communication techniques? Undoubtedly, mechanized in-

\footnotetext{
${ }^{10}$ Informal conversation with Harvie Branscomb,
} 
formation retrieval will come to the junior college library as it will eventually come to all kinds of libraries. It is already being used experimentally in all kinds of libraries. In many cases, the information system will use the college computer. The fact that automation seems expensive should not retard its use. If library services are improved by automation, then the expense is worthwhile. Librarians have not always sought improved services as forcefully as they should. Of course, the sophistication to use such devices successfully must be developed, but the trend among junior college librarians to adopt audiovisual aids suggests a readiness to consider other devices also.

It seems clear that strong medicine is needed for these libraries. Perhaps this means strong federal support. Perhaps it means strong ACRL lobbying with college presidents. Perhaps it means a stronger breed of junior college librarians. At any rate, the future should be exciting.

\section{ACADEMIC STATUS . . .}

\section{(Continued from page 210$)$}

But "faculty," as understood by the great German universities that arose concomitant to and following the rise of the last, Leibnizian, type of academy, was Fach, "a discipline." To be a Fachmann was not regarded as anything other than to be a profess-or of a subject, a specialist. To what Fach then would the librarian belong except that of library science? But the librarian need not teach to be academic; indeed, to teach puts the librarian in a less secure academic position than to select or catalog books, etc. The library science faculty is no more proof against the charge of mere processing of students than any other teacher-less, in fact, due to the vocationalism of many such faculties.

Thus, within the faculty (Fach) are found ranks, the ordinary means of self- preservation of the alienated. The Fach is alienated within the universitas except by academic communing, which places the Fachmann on a new level, outside his narrow specialistic professionalism: the status of academician.

\section{EPILOGUE}

Academic status then, as viewed in the transparency of the situation, is a qualification added to that (for teachers) of faculty rank or to that (for librarians) of professional standing. It is not automatically predicated on either of these types of professional persons, but rather is a feature of the institution to which they belong. Like "standing," status implies a level, but not the discrete "I'm higher in rank than you," characteristic of faculty rank, but rather implies one level, the single plane of overt communing as determined by the nature and orientation of the institution. Such overt communing can take place only within the book environment which the librarian in a sense is. Without teaching, without even ever coming into personal contact with his fellow academicians, in an overt communing that can remain quite impersonal, the librarianas selector, cataloger, and servicer of the library-is the typical academic.

\section{BOOK SELECTION . . .}

(Continued from page 224)

of graduate facilities and resources. They are less reliable, however, when it comes to agreeing on the basic works in their field. You can get as many statements of what is essential and considered "standard" in each discipline as individuals you might wish to consult. Under these circumstances, it becomes the librarian's responsibility to acquaint the faculty with sound principles of book selection and a clear understanding of his acquisition problems and budgetary limitations. Only then is real cooperation possible. 